\title{
A escrita performática como discurso político e a trilogia metadramatúrgica gogoliana
}

Performative Writing as political discourse and Gogol's meta-dramaturgical trilogy

Rebeka Caroça Seixas ${ }^{1}$ 


\section{Resumo}

No presente artigo, desenvolver-se-á um estudo de como o conceito de performance pode ser aplicado à escrita, utilizando para isso as pesquisas de diferentes autores, visando compreender o tema por diversas perspectivas. O estudo da performatividade da escrita se apresenta como um estudo relativamente novo em que as pesquisas têm se intensificado a partir do início do século XXI. Na sequência, trabalhar-se-á na enumeração dos diferentes conceitos que podem constituir uma escrita performativa, dentre os quais podemos destacar: "eu escrevente", "autor performer", "coescritor performático", "escrita de si" e "narrativa performática". Durante o estudo do conceito, trabalhar-se-á com aspectos biográficos do dramaturgo Nikolai Gógol e elementos da sua trilogia metadramatúrgica (O Inspetor Geral (1836), À Saída do Teatro Depois da Representação de uma Nova Comédia (1842) e Desenlace de O Inspetor Geral (1846)).

Palavras-chave: Nikolai Gógol; metadramaturgia; escrita performática; discurso político

\section{Abstract}

In this paper, we will develop a study on the application of the concept of performance in writing, using several authors' research to understand the theme through multiple perspectives. The study of writing performativity is relatively new, with an intensification of research works happening since the beginning of the 21st century. Subsequently, we will enumerate the different concepts that can support performative writing, amongst which we can highlight: "Writer me", "performer author", "performative co-writer", "writing of oneself", and "performative narrative". During the conceptualization, we will work with biographical aspects of the playwright Nikolai Gógol and with elements of his meta-dramaturgical trilogy, (The Government Inspector (1836), Leaving the theater after the performance of a new comedy (1836), and Denouement of The Government Inspector (1846).

Keywords: Nikolai Gógol; meta-dramaturgy; performative writing; political discourse 


\section{Introdução}

As pesquisas sobre a performance no campo da literatura e da escrita ainda são escassas, mas existe uma necessidade de se buscar novos caminhos para o estudo de uma escrita que esteja mais voltada para a colocação do artista na obra, onde o autor seja também um atuante do processo de transmissão da mensagem e na relação obra leitor/espectador. Este trabalho, que encontra o seu fio condutor na discussão do que é uma escrita performática e como ela pode ser utilizada na análise de uma obra literária, tendo como referência a trilogia metadramatúrgica do escritos russo Nikolai Gógol².

A escrita como um processo de elaboração e construção, ao longo do desenvolvimento cultural de alguns grupos sociais no ocidente, esteve associada ou diretamente ligada a uma relação dicotômica entre dominador e dominado. Servindo muitas das vezes como ferramenta de representação da cultura ou do grupo social hegemônico de seu tempo, estabelecendo a relação entre cultura superior e inferior, que Diana Klinger (2006) vai chamar de "dominação por meio da letra" (Klinger, 2006, p. 190). O que a performance propõe para a atividade da escrita é justamente a quebra dos dualismos e a desierarquização das relações existentes no ato da escrita. A performance dota de voz e existências os envolvidos nesse processo de escrita, de maneira a anular o pêndulo entre autor-leitor, retratador e retratado. $O$ que existe são pulsões e fluxos de existências que parecem jogar com a revelação e ocultação das identidades. Ora percebemos as diferentes vozes presentes em um texto a ponto de identificar minimamente as identidades e hora essas identidades são ocultadas e tudo se transforma na voz plural de um autor. O que a performance na escrita traz de contribuição é exatamente a percepção de que um autor não fala sozinho e não se constitui como uma voz suprema e isolada, mas antes, ele é o instrumentista que toca os acordes das vozes que o compõe e participam de seu processo de existir-resistir-coabitar no mundo.As fronteiras entre performance e escrita tendem a se abrandarem, uma vez que ambas podem se servir uma da outra para chegarem a objetivos singulares. Discutiremos os conceitos que permeiam essa junção entre a escrita e a performance nas zonas de fronteira e o hibridismo que esse estudo confere.

A escrita performática está presente em um evento onde o autor e o leitor são sujeitos da obra e estão em aproximação no momento da escrita e da leitura. Segundo Patrice Pavis, em seu livro A Encenação Contemporânea: origens, tendências, perspectivas (2010), "[...] a performance indica que uma ação é executada pelos artistas e que também é o resultado dessa execução" (Pavis, 2010, p. 44), assim, a ação é destacada enquanto geradora de sentido. $O$ enfoque é na ação daquele que escreve, porém, sem deixar de lado os significantes envolvidos na ação daquele que lê. $O$ trabalho dramatúrgico de Gógol pode ser pensado pelo viés da escrita performática devido a alguns aspectos chaves como: a sua inscrição dentro da obra, onde suas opiniões sobre o teatro e a relação com a crítica estão impressas, ou seja, existe a sua inserção no discurso enquanto autor que não apenas apresenta uma obra, mas é

\footnotetext{
${ }^{2}$ Nos referimos aqui as três obras elencadas na tese "Metadramaturgia e escrita performática na obra dramatúrgica de Nikolai Gógol" defendida em 2016. Na referida tese, trabalhou-se com as obras: O Inspetor Geral (1836), À Saída do Teatro Depois da Representação de uma Nova Comédia (1842) e Desenlace de O Inspetor Geral (1846), as quais denominamos de trilogia metadramatúrgica gogoliana (Seixas, 2016).
} 
parte dela; a relação estabelecida entre o autor e o leitor/espectador, uma vez que Gógol, principalmente em suas obras metadramatúrgicas, apresenta diversos elementos da linguagem, assim como chama atenção para aspectos da crítica na busca de gerar reflexões; sua atividade artística extrapola o campo da escrita e abrange o campo político, assim como aborda aspectos referentes à atividade dramatúrgica; inicia a busca por uma escrita diferenciada, sendo o pioneiro do movimento realista na Rússia.

Essa pesquisa objetiva pensar a escrita como sendo o próprio autor, uma escrita de si, mas também uma escrita do mundo, pois quando escreve, o dramaturgo não se distancia da realidade onde está. O resultado, que Michel Foucault, no livro O que é um autor? (2011), denomina como a 'escrita em si', é sempre um olhar de quem, de forma direta ou indireta, está inserido no processo de produção da obra de arte. Se levantarmos esta reflexão no campo da literatura, poderíamos então entender que uma escrita performática deve estar diretamente ligada à relação entre autor e leitor, em um jogo de significantes e significados que são produzidos e construídos durante o período em que essa relação se estabelece. O que diferencia a escrita gogoliana é justamente o desejo de Gógol, enquanto artista, de participar de vários elementos de sua obra simultaneamente e não se contentar apenas em escrever literatura, mas estar dentro da literatura, ou seja, colocar no discurso de suas obras o seu próprio discurso político e artístico. Neste estudo, tomar-se-á, como exemplo, alguns aspectos da vida e da obra de Nikolai Gógol para que se possa desenvolver as teorias abordadas pelos autores que são a base referencial para esta pesquisa.

\section{A escrita performática e seus desdobramentos}

No estudo intitulado Ficción y performance en escritores latinoamericanos contemporâneos (2001), Graciela Ravetti expõe alguns aspectos do que vai se delineando como performance da escrita e que ela denomina inicialmente de "narrativa performática". Segundo a autora:

[...] utilizo a expressão 'narrativa performática' para me referir a tipos específicos de textos escritos em que certos recursos literários que compartilham a natureza da performance, segundo a acepção desse termo, em sentido amplo, no âmbito cênico e no político-social. [...] tomo a conhecida fundamentação de John Austin sobre o conceito de performativo, no sentido de que em toda a enunciação o falante está comprometido com algum tipo de ato, ilocutório, que modifica e determina a relação entre os interlocutores. A tudo isso, não podemos deixar de somar os conceitos de Foucault sobre o poder performativo conceptual do discurso e muito menos podemos ignorar as argumentações de Lacan sobre o que significam a linguagem e a interpelação na formação do sujeito. Teria, então, duas expressões complementares: 'narrativas performáticas' e 'vínculos performativos'. As primeiras - as narrativas performáticas - poderiam vir a ser decisivas no momento de questionamento e da resistência ao segundo - os vínculos performativos - nascidos nas instâncias do poder estabelecido (Ravetti, 2001, p. 51)

\footnotetext{
3 “[...] utilizo la expresión 'narrativa performática' para referirme a tipos específicos de textos escritos en los cuales ciertos rasgos literarios comparten la naturaleza de la performance, según la acepción de ese término, en sentido amplio, en el ámbito escénico y en el político-social. [...] tomo la conocida fundamentación de John Austin sobre el concepto de performativo, en el sentido de que en toda enunciación el hablante está comprometido con algún tipo de acto, ilocutorio, que modifica y determina la relación entre los interlocutores. A todo eso no podemos dejar de sumar los conceptos de Foucault sobre el poder performativo conceptual del discurso y mucho menos podemos ignorar las argumentaciones de Lacan sobre lo que significan el lenguaje y la interpelación en la formación del sujeto. Habría, entonces, dos expresiones complementarias: 'narrativas performáticas' y 'vínculos performativos'. Las primeras - las narrativas performáticas - podrían venir a ser decisivas al momento del cuestionamiento y de la resistencia a los segundos - los vínculos performativos - nacidos a instancias del poder establecido" (Ravetti, 2001, p. 51 - Tradução nossa).
} 
A "narrativa performática" seria aquela em que o emissor se compromete com uma ação de comunicação que modifica sua relação consigo e com os receptores da sua obra. Na troca que se estabelece entre aquele que escreve e aquele que lê, ambos estão em exposição, seja o que escreve, no ato de doação, de usar sua voz para reverberar um discurso, ou aquele que lê, que se abre para o universo criado e que encontra ali um mundo a ser explorado.

Nesse processo de escrita, o autor trabalha com a ordenação e com as ideias que são apresentadas por um jogo cuidadoso de palavras. Uma escrita surge voltada para uma suposição de valores, imprimindo um ritmo para o leitor, cadenciando a forma de apreensão da mensagem e dando lugar a uma escrita que quer convencer, inclusive ao ordenar sentimentos e perspectivas autorais. A escrita performática seria uma escrita onde o leitor participaria como um "coescritor performático", como cita Juliana Leal (2008). Segundo a autora, o "coescritor performático" é o leitor/espectador que consegue desenvolver uma imagem mental da obra literária e que não é mais escravo do autor, mas estão, ambos, empenhados no exercício de compor uma escrita performática. Assim, Gógol estabelece uma relação intensa com o leitor ao tentar, em maior grau em suas obras metadramatúrgicas e em menor grau nas demais obras, levá-lo à uma reflexão.

No sentido defendido por Ravetti (2001), de uma "narrativa performática", podemos compreender que Gógol, ao criar uma obra metalinguística, chama atenção para suas questões, para a dificuldade de aceitação, pela crítica, da obra O inspetor geral. A perspectiva do autor é colocada em evidência para possibilitar uma reflexão do espectador sobre diversos aspectos da obra teatral. A recepção da peça foi diversa, alguns concordavam com o que era exposto, outros discordavam e achavam que não deveria mais ser exibida e que o autor deveria ser punido. Dessa forma, podemos perceber que sua obra dramatúrgica teve um impacto considerável no contexto em que foi lida e/ou exibida inicialmente.

Essa ideia de "coescritor performático" sintetiza bem o espaço que o leitor/espectador ganha dentro da obra. O processo hierárquico existente em anos de produção escrita, entre esses dois agentes do processo de constituição da literatura, obra e leitor, e sem os quais a obra deixa de existir de maneira completa e única. Utilizaremos o termo "coescritor performático", de Ravetti, para nos referir ao leitor/espectador que também é, além de participante ativo da escrita performática, um leitor vivo que, ao mesmo tempo em que lê, é lido pela obra e se reconhece no seu conteúdo.

O "coescritor performático", juntamente com o autor, é o cerne da escrita performática e sem esta relação estabelecida, a escrita não se perpetua como uma ação, que por si só é performativa. Quando Gógol expõe, em À saída do teatro depois da representação de uma nova comédia e $O$ desenlace de $O$ inspetor geral, os bastidores de sua principal obra, $O$ inspetor geral, e apresenta os comentários feitos à peça através de personagens das diversas esferas da sociedade russa, além de o autor informar

\footnotetext{
${ }^{5}$ Natsu Nakajima (1943 -) dedicou toda a vida à dança Butô sendo um dos membros fundadores desse movimento e uma das principais pioneiras dessa dança fora do Japão. Aos 19 anos, ela entrou no Kazuo Ohno Dance Studio e apenas um ano depois começou a trabalhar com Tatsumi Hijikata. Treinando com esses dois grandes mestres, Nakajima, em 1969, estabelece sua própria companhia de dança chamada Muteki-sha, onde atuou e coreografou internacionalmente desde o início dos anos 1980 . Além de seu desempe
} 
sobre um dado real, permite que o "coescritor performático" se posicione, analise as diversas críticas e aspectos levantados e possa, a partir daí, chegar a construir sua própria visão.

A relação de presença, a partir da voz do autor que surge da obra, conduz o leitor de forma crítica, expõe ideias para além da própria obra e estabelece relações entre as operações culturais existentes na época de sua origem e nas atuais. Essas são relações que o leitor de hoje elabora e através das quais vai dando vida e significado à obra que renasce na leitura contemporânea. Ao entrar no universo de escrita do autor, entramos também em um universo de palavras, de signos e no ritmo que é impresso por ele próprio, ao fazer as possíveis relações entre aquele que escreveu a obra, aquele que lê e todas as significações que podem estar inseridas nesse entremeio. Para se referir ao autor que expõe o seu "eu" na obra de arte e que utiliza em sua escrita elementos que estão deslocados do seu lugar de origem, será utilizado o termo "autor performer"4.

No tocante à obra dramatúrgica gogoliana, o universo criado é cômico e foi através do riso que o autor resolveu pautar suas indagações a respeito da sociedade, da política e do teatro, visto que todas as suas cinco peças são comédias. As situações apontadas por Gógol são situações reais, de corrupção, de cobrança de propina, entre outras. Seus personagens querem sempre ganhar vantagem de alguma forma e, nesse sentido, as semelhanças com situações do cotidiano de qualquer cidade podem ser reconhecidas. Esse reconhecimento que o "autor performer" provoca no "coescritor performático" é um dos elementos que faz com que a obra seja atemporal. Assim, o elemento metadramatúrgico é de extrema importância para a performatividade da escrita gogoliana, justamente por expor, de forma clara e direta, os bastidores da cena e a visão do autor sobre diferentes aspectos da linguagem, sem perder o aspecto cômico.

Sobre a escrita e suas inter-relações com o meio social, Foucault (1964, p. 147) diz:

Ela detém a essência da literatura, mas dá ao mesmo tempo sua imagem visível, real. Neste sentido, pode-se dizer que toda a obra diz o que ela diz, o que ela conta, sua história, sua fábula, mas além disso, diz o que é literatura. Acontece que ela não diz em dois tempos: um tempo para o conteúdo e um tempo para a retórica; ela o diz em unidade.

A metadramaturgia 5 é um ponto importante para a produção das inter-relações entre a escrita e o meio social, uma vez que, para o filósofo, a escrita é, na verdade, uma metanarrativa do que é literatura. Foucault estabelece um contraponto entre a essência e o visível, material e real, visto que essa dualidade explicitada constitui o que é performativo na obra.

Sobre essa questão, Denise Pedron (2006) afirma que uma escrita performática perpassa por algumas características: (i) o autor sai do papel de mero escritor e passa

\footnotetext{
${ }^{4}$ Esse termo foi cunhado por Alex Beigui, no artigo Guimarães Rosa ou o narrador como performer, publicado em 2013.

${ }^{5} \mathrm{O}$ estudo sobre metadramaturgia objetiva compreender de que forma se estruturam as peças que abordam o exercício da dramaturgia, bem como seus elementos. A metadramaturgia se configura como uma subcategoria do metateatro, que tem como base, segundo nossos estudos, os seguintes elementos: aspecto citacional, teatralidade, desnudamento dos códigos da linguagem dramatúrgica, autocrítica, personagens autônomas, autorreferencialidade, consciência dramática dos personagens e quebra com o ilusionismo da cena. Esses elementos podem ser aplicados no estudo de obras (Seixas, 2016).
} 
a ganhar lugar na enunciação que se desenvolve a partir de uma forte intervenção social e política, (ii) a crítica a aspectos sociais e à realidade em que a obra está inserida; (iii) a visão do corpo daquele que escreve e daquele que lê, como agenciadores simbólicos onde as pulsões corporais agem como operadores de sentido da escrita; (iv) a palavra, não mais como poder primeiro, mas em constante diálogo com as artes de maneira geral.

Ao analisarmos os pontos propostos por Pedron (2006), a respeito da escrita performática aplicados à obra dramatúrgica de Gógol, conclui-se que: (i) o autor, a partir do recurso metadramatúrgico, cria um personagem para que possa ganhar lugar na enunciação ("O Autor da Peça" pode ser citado como exemplo) e aborda temas sociais, políticos e estéticos em seus discursos, (ii) usa sua obra como objeto de crítica a diferentes aspectos da sociedade russa, (iii) insere questionamentos nos personagens que o próprio leitor deve fazer a si no decorrer da leitura e (iv) a partir desses questionamentos e da exposição dos elementos da linguagem teatral, o autor estabelece o diálogo direto e constante com o "coescritor performático".

Sobre esse processo de escrita, Foucault (2011, p. 144) diz:

Pode-se portanto dizer que, a partir do século XIX, todo o ato literário se apresenta e toma consciência de si como transgressão da essência pura e inacessível da literatura. E, no entanto, em outro sentido, cada palavra, desde sua escrita na famosa página em branco da obra, faz sinal para algo - pois não é palavra normal ou comum - que é a literatura; cada palavra é um sinal que indica algo que chamamos literatura. Pois, para dizer a verdade, nada em uma obra de linguagem é semelhante àquilo que se diz cotidianamente. Nada é verdadeira linguagem. Não há uma única passagem de uma obra que possa ser considerada extraída da realidade cotidiana.

A partir do século XIX, o caráter transgressor que o ato literário assume faz cair a ideia de uma literatura que só é acessível aos acadêmicos ou aos mais letrados. Aos poucos, o acesso à literatura vai se tornando mais fácil e menos temeroso para os leigos e os artistas vão explorando cada vez mais o poder da linguagem, no sentido de romper com as regras e fugir dos padrões literários vigentes. O filósofo também destaca a importância dos significantes de cada palavra, de cada pontuação e de cada linha que compõe o discurso do artista. Segundo ele, nada do que se escreve em uma obra literária é em vão, tudo "faz sinal para algo", ou seja, significa, ressignifica e recria o universo proposto pelo artista. A visão de um autor distante e que não interage com o seu leitor é deixada de lado em detrimento de uma aproximação entre o texto e o contexto, digo um contato ativo entre emissor e receptor.

Segundo Alex Beigui (2011, p. 25):

A disseminação do campo da performance exige um redimensionamento do lugar da escrita no campo das letras e da linguagem, pois na junção que estabelece entre diversos modos de subjetivação envolvidos na prática escritural, ela evidencia os aspectos relacionais entre a escrita e a inscrição do sujeito no discurso que a produz, seja ele de natureza literária, ficcional ou crítica.

O autor passa a ser o sujeito que produz um discurso em que está impresso a si próprio. O dramaturgo, ao retratar em suas peças a Rússia e seu regime opressor, desenvolve um pensamento crítico com relação ao sistema político daquele país, o 
contexto está imbricado em suas peças, assim como está marcado no próprio Gógol, como um reflexo de si. Levando em consideração o que Foucault vai chamar de "impureza letal da palavra", ou seja, todo texto escrito carrega em si o desdobramento da palavra que não diz respeito somente ao autor e sim, ao receptor, Gógol vai jogar, explorar e trabalhar com as palavras de maneira a fazer delas uma arma contra o contexto social e político de sua época e esse uso da escrita, por si só, já pode ser considerado performático.

Segundo Beigui (2011, p. 31), "Literatura é performance, garatuja, desenho impróprio da gramática, desvio da sintaxe; com ela aprendemos que o cotidiano e a existência podem ser insuflados pelos fatos da própria vida, vida em potência". Podemos, então, apontar para a relação autor versus texto versus contexto, onde o autor não se distancia do que está ao seu redor no ato da escrita. Sobre esta relação entre autor e contexto, Diana Klinger, em sua tese intitulada Escritas de si, escritas do outro: o retorno do autor e a virada etnográfica, escreve:

[...] exposição radical do si mesmo, do sujeito enunciador assim como do local da enunciação; a exibição de rituais íntimos; a encenação de situações autobiográficas; a representação das identidades como um trabalho de constante restauração sempre inacabado (Klinger, 2006, p. 60).

A esse autor que expõe suas fraturas na própria obra, a autora vai denominar de "eu-escrevente". Essa exposição radical de si, à qual Klinger se refere, é a exposição a que o autor se submete ao escrever um texto performático, pois, assim como a performance enquanto prática artística se desenvolve com o "eu" do performer exposto e desvelado na frente do espectador, a escrita performática desvela o "eu" do "autor performer". A este cabe utilizar a escrita, enquanto uma transgressão, como um mecanismo de crítica e de reivindicação a partir das experiências pessoais que estarão impregnadas na sua obra. No que se refere a "encenações de situações autobiográficas", exposto por Klinger, podemos citar como exemplo as peças metadramatúrgicas de Gógol, onde o autor traduz, através da fala de seus personagens, a revolta, o constrangimento e a ira que foram insufladas pela crítica russa às suas obras. Essa escrita ultrapassa o que há de literário e passa a ser um ritual de desabafo e de exposição.

Sobre esse entendimento da obra, como uma possível ritualização da escrita e da inscrição do autor, Alex Beigui (2011, p. 28) diz:

Performances da escrita envolvem o 'desempenho' de autoentendimento que a natureza do discurso insiste em realizar, aspecto que intensifica o ato incansável de perdurar, existir, viver-morrer através da escrita. A relação entre vida e arte pode ser comparada, na literatura, com 'entrelugares': Eros e Tânatos, vida e morte, prazer e dor, cuja fisicalidade do horror de parecer se faz carne e se faz verbo no corpo, sempre corpo, do texto.

O trecho traduz exatamente o que a escrita é para Gógol, um "viver-morrer", um "se entregar inteiramente", ao expor fragilidades, incertezas e insegurança, assim como certezas, reivindicações e revoltas, em um jogo constante de antíteses. Beigui também trabalha com o significado da palavra corpo e, nessa perspectiva, podemos pensar de três maneiras distintas: o corpo daquele que escreve, o corpo daquele que lê e o corpo do texto. Na primeira perspectiva, temos: o autor que coloca em sua obra 
de arte aquilo que reverbera em si; enquanto na segunda, o corpo "eu escrevente" é provocado, mexido e revirado pela escrita; por fim, na terceira, há o corpo do texto, que une o "eu escrevente" e "coescritor performático" em uma simbiose infinita.

O corpo sempre esteve diretamente ligado à performance, principalmente no que se refere à body art e à action painting. No caso específico da escrita performática, o corpo do autor estende esse viver-morrer para uma escrita que pretende perpetuar o discurso do artista. A partir dessa afirmação, pode-se dizer que Gógol expõe em sua obra as questões que reverberam em si, aquilo que o motiva e o que desmotiva, o que o impulsiona e o que o retrai, o que aponta o caminho e o que o turva. Assim, esse seria o primeiro ponto de uma perspectiva corporal do "autor performer". Essa utilização da própria obra para escrever suas pulsões corporais provavelmente gerou as crises que fizeram com que o dramaturgo russo se exilasse de seu país por diversas vezes. O segundo ponto seria o reverberar do discurso do "autor performer" e o quanto ele é capaz de tocar, mexer, instigar o "coescritor performático", principalmente no que diz respeito a aspectos sociais, políticos e estéticos.

A revolta que a obra gogoliana causou em sua época, os comentários e protestos que gerou, falam muito sobre esse aspecto de interação com o "coescritor performático". Através de suas peças, Gógol conseguiu atingir uma reflexão política, talvez não na dimensão e viés que ele pretendia, mas que provocou e reverberou no público. O terceiro ponto seria a interação entre o corpo do texto e a união por ela gerada, ou seja, entre o "autor performer" e o "coescritor performático", relação que se efetiva em Gógol não somente nos momentos de leitura, mas de encenação de suas obras. Nesse sentido, a obra dramatúrgica apresenta duas possibilidades de interação, uma delas pelo viés da leitura solitária do texto e outra na apresentação do texto encenado. Nos dois sentidos, o corpo do texto é que estabelece a relação entre o corpo do "autor performer" e do "coescritor performático".

Sobre os aspectos relacionados entre o corpo e o texto e, principalmente, no que se refere ao corpo daquele que lê, Paul Zumthor, em seu livro Performance, recepção e leitura (2000, p. 23), nos diz que:

O que entender aqui pela palavra corpo? Despojado como ele está em minha frase, parece escapar, por demasiado puro e abstrato, ideal [...]. No entanto, é ele que eu sinto reagir, ao contato saboroso dos textos que amo; ele que vibra em mim, uma presença que chega à opressão. O corpo é a materialização daquilo que me é próprio, realidade vivida e que determina minha relação com o mundo. [...] é ele que eu vivo, possuo e sou, para o melhor e para o pior. Conjunto de tecidos e de órgãos, suporte da vida psíquica, sofrendo também as pressões do social, do institucional, do jurídico.

Esse corpo que Zumthor (2000) aborda pode ser muito bem representado quando se estuda a obra dramatúrgica de Gógol, visto que o autor russo é um exemplo de que seu corpo e sua arte não se distanciaram em nenhum momento, até a sua morte. Gógol viveu tão intensamente sua escrita que deixou-se morrer abalado pelos rumos que sua obra tomou. Talvez o artista não tivesse a noção de que sua escrita poderia, depois de publicada, ganhar caminhos diferentes daquele que planejara.

O corpo em relação ao texto, em um cruzamento de sensações, onde as percepções se somatizam, as palavras que reverberam no meu corpo e por ele se espa- 
Iham e com ele rivalizam, apaixonam, odeiam e amam, em uma mesma experiência, ou seja, a experiência de interação sinestésica com o texto. A percepção de Zumthor aponta para as reações físicas que a obra literária provoca, ou seja, de que maneira ela age no corpo do receptor e de que maneira ela pode influir não só no momento da leitura, mas nas provocações e mudanças que podem ser levadas para a vida social. Nessa relação, entre o corpo do "coescritor performático" e a obra, é que está um dos pontos de ação da escrita performática, uma vez que é através do olhar do leitor/espectador que a obra se efetiva como uma obra performativa e não apenas contemplativa, no sentido de representação. Se partirmos do princípio que a escrita performática é uma escrita em que o autor escreve e se inscreve na obra, o seu corpo está diretamente ligado ao sentido que produz a obra de arte, no que diz respeito ao aspecto político e estético. Para Beigui (2011, p. 29):

\footnotetext{
A presença de uma tensão entre os diversos níveis de imparcialidade e parcialidade leva a escrita a um ato cognitivo de 'performar' as diversas maneiras que o corpo encontra de se manter, se dizer na extensão que o ato de escrever-pensar-sentir permite. Escrever, talvez, tenha sido o primeiro ato performático consciente desde os tempos em que os homens lançavam seus desenhos nas cavernas, até o encontro com as formas idiomáticas e discursivas de representação.
}

A extensão do corpo como escrita, que simboliza o sujeito, é uma tradução consciente do inconsciente do autor. Ao pensarmos a performance enquanto ação que envolve primeiramente o próprio artista, a escrita passa a ser vista como exercício em que o corpo se torna o meio e o fim de toda a obra. Para Graciela Ravetti (2001), "a performance escrita passa também pela idiossincrasia do corpo" (Ravetti, 2001, p. 20). O ato de escrever, como princípio para a produção de qualquer obra, faz uso do corpo que se envolve no ato da escrita, no ato de "sentar e escrever". A ação física que se desenvolve quando o autor resolve iniciar sua obra, quando o artista é movido pela pulsão, é uma ação performativa no sentido de colocação do artista e de sua relação com o que está a sua volta.

$\mathrm{O}$ ato prazeroso de escrever também reside na satisfação da leitura, visto que ocorrem de forma orgânica, ou seja, o corpo se envolve totalmente na obra, seja o corpo do "eu escrevente" ou o corpo do "coescritor performático" e, assim, ambos são envolvidos no que denominamos escrita performática. Sobre essa dicotomia, Roland Barthes, em seu livro O prazer do texto (2006), aborda a questão do prazer de se escrever e ler um texto. Para o autor, assim como cada texto é singular, cada leitura também o é. Um novo prazer é experimentado pelo "coescritor performático" a cada nova leitura. A escritura, para Barthes, é uma estimulante pulsão à curiosidade, ao elevar o indivíduo à descoberta do prazer. Segundo ele: "Para o texto, a única coisa gratuita seria sua própria destruição: não escrever, não mais escrever, salvo do risco de ser sempre recuperado" (Barthes, 2006, p. 32). O texto, após publicado, pode ser "recuperado", ou seja, ser relido e ressignificado.

A leitura de um texto, enquanto algo que reverbera, segundo Barthes, produz um prazer comparado ao sexual, ou seja, "[...] produz em mim o melhor prazer se consegue fazer-se ouvir indiretamente" (Barthes, 2006, p. 32). Segundo ele, o ato de escrever induz a um amor às palavras e ao gozo na relação com o significante, em sua 
apreensão, "O prazer do texto é isso: o valor passado ao grau suntuoso de significante" (Barthes, 2006, p. 77). Esse prazer é provocado pela ação da escrita, no caso do "autor performer", e na forma como o texto é lido pelo corpo, no caso do "coescritor performático".

Para Zumthor (1994, p. 77), "As palavras resistem, elas têm uma espessura, sua existência densa exige, para que elas sejam compreendidas, uma intervenção corporal", o autor se dedica a pensar sobre o corpo daquele que lê, esse corpo que está em contato com os textos e que também está em contato com o meio social, político e cultural. Quanto à materialidade do texto, percebe-se também a questão do contato com o corpo, no que se refere ao tato imbricado no ato da leitura, o sentido da visão utilizado na decodificação e interpretação dos textos, das palavras, daquilo que está sendo dito e de como está sendo dito. Essa intervenção corporal, de que nos fala Zumthor, é a intervenção do "coescritor performático", o que há de performativo na escrita passa por essa tríade: corpo do "eu escrevente", corpo do texto e corpo do "coescritor performático".

Além da relação estabelecida entre corpo e autor, corpo e "coescritor performático", podemos frisar algumas outras relações geradas pela escrita performativa como sendo também primordiais para essa discussão: (i) a utilização do texto performático como um arquivo; (ii) a relação estabelecida com outras linguagens artísticas; (iii) a crítica e a utilização de elementos políticos e culturais; (iv) a presença de uma certa oralidade que se materializa no ato da leitura e (v) a capacidade de visualização das imagens suscitadas pelo texto. É importante frisar que quando nos referimos à potência política da escrita performática, não queremos dizer que existe uma obrigação de representação fiel da realidade ou de um acontecimento político. Não há um comprometimento com o real, nem uma obrigação com a denúncia de um fato ou com a reivindicação por melhores condições para as minorias.

A escrita performática expõe preconceitos, desvios de conduta e posturas ou atitudes antiéticas, sem o compromisso de uma representação ilusionista. Os poetas russos que desenvolveram seus trabalhos no final do século XIX e início do século $X X$, podem ser usados como exemplo dessa exposição de preconceitos e de condutas antiéticas. A ironia, a independência, a malícia, a exposição e ridicularização de diversas esferas do governo, muito presente na literatura russa deste período, são elementos importantes de uma escrita performativa que, por mostrar um olhar do artista, muitas vezes, expressa uma desconfiança e suscita no leitor uma reflexão.

Sobre esse aspecto, Vladimir Nabokov (2014, p. 30) aponta nas obras daquele que ele julga ser o primeiro grande escritor russo, Alexander Púchkin, aspectos maliciosos, em que se configurava uma "perigosa liberdade de pensamento" além da ridicularização de tiranos. Assim, pode-se perceber que no contexto em que Gógol produziu suas obras havia uma efervescência artística, uma busca dos autores por um espaço que era muito bem fiscalizado pelo regime político da época. Esses autores produziram obras que abriram espaço para a equiparação da literatura russa à literatura de países como a França e a Inglaterra.

Para Foucault (2009, p. 267), a "[...] noção de autor constitui o momento crucial da individualização na história das ideias, dos conhecimentos, das literaturas, e também na história da filosofia, e das ciências", ou seja, a partir do momento em que se 
passa a ter consciência de que o autor existe, passa-se então a individualizar os discursos e a lhes conferir certa unidade. Neste sentido, Foucault (2009, p. 268) esclarece:

Pode-se dizer, inicialmente, que a escrita de hoje se libertou do tema da expressão: ela se basta a si mesma, e por consequência, não está obrigada à forma da interioridade: ela se identifica com sua própria exterioridade desdobrada. $\mathrm{O}$ que quer dizer que ela é um jogo de signos comandado menos por seu conteúdo significado do que pela própria natureza do significante; e também que essa regularidade da escrita é sempre experimentada no sentido de seus limites; ela está sempre em vias de transgredir e de inverter a regularidade que ela aceita e com a qual se movimenta; a escrita se desenrola como um jogo que vai infalivelmente além de suas regras, e passa assim para fora. Na escrita, não se trata da manifestação ou da exaltação do gesto de escrever; não se trata da amarração de um sujeito em uma linguagem; trata-se da abertura de um espaço onde o sujeito que escreve não para de desaparecer.

A escrita como algo que se basta em si própria, como coloca Foucault, é uma escrita que foge dos padrões e não se obriga a um enquadramento dentro desse ou daquele padrão. O autor enfatiza a escrita como prática, não mais como resultado, e constata que a escrita está liberta da ideia de expressão, de algo que representa um sentimento do autor. Para o filósofo, a importância reside na exterioridade dessa escrita e na natureza de seu significante. A escrita é vista, então, como agente transgressor, que ultrapassa aquele que a escreve, ao superar a ideia de uma regularidade e de algo que pode ser formatado.

É importante destacarmos também a relação entre o texto e o contexto na escrita performática, para a facilitação do binômio autor e "coescritor performático", uma vez que, quando a relação entre texto e contexto é bem percebida, tanto pelo autor, quanto por aquele que lê, essa relação entre os dois agentes pode ser estabelecida em maior intensidade. Assim, tanto o texto pode influenciar o contexto, como o inverso também pode ocorrer, ou seja, um a perpassar ou modificar o outro e, assim, através dessa dualidade, pode-se delinear o posicionamento do "eu escrevente" e sua relação com o "coescritor performático". Sobre as transformações que podem envolver texto e contexto, Beigui (2011, p. 29) aponta:

[...] para cada texto poético, há uma vida poética, não prenhe de sentido ou portadora de sentido, mas, inexoravelmente, de presença. Aliás, toda a crise do drama pode ser refletida na crise do sentido que atravessou as linguagens artísticas assumidas no pós-guerra como metaficção do holocausto, como metaficção da história, como metaficção da própria ficção. Ruptura não só com as categorias de evidência, mas investigação sobre a evidência da crítica formal e seus modos de manipulação do e sobre o texto.

A ideia da escrita como presença, enquanto materialidade, que todo texto escrito traz consigo e a presença do discurso que vai além do sentido, que os críticos tanto tentam trazer para a obra de arte, que ultrapassa o próprio autor e que atinge o "coescritor performático" em diversos níveis, incluindo o físico, como aponta Zumthor, é o que a faz dinâmica, viva e aberta às possíveis trocas que podem ocorrer no contato com o "coescritor performático".

A noção de um coescritor se reporta diretamente à relação de crítica presente na escrita performativa e que faz com que o leitor tenha um papel ativo no processo de 
significação. A presença da crítica, na escrita performática, e a importância de haver um caráter de denúncia ou de protesto, ou ainda de exposição de preconceitos e de colocação do artista diante da sua realidade, é evidenciada por Beigui (2011, p. 29):

No limite dos signos, as arestas são alimentadas em atos de uma escrita que 'performatiza' o horror, a violência, a dormência dos sentidos, a impotência do Estado em suas diferentes frentes de atuação e, principalmente, a conquista da ética como última forma redentora dos homens.

Nesse sentido, pensar uma escrita performática não é pensar em uma escrita presa somente ao seu tempo, mas pensar uma escrita que ultrapassa seu tempo e, ao longo da história, torna a se reinventar a partir de contextos outros que não aquele que a fez surgir. Diante disso, pensar no projeto existencial do autor e a questão da sua presença na obra, é um tema extremamente relevante para a discussão sobre a escrita de si, enquanto uma escrita que estamos denominando performática. A maneira como essa técnica ultrapassa séculos e se funde a outras culturas diferentes da "original" em que a obra foi escrita também diz muito sobre a universalidade do discurso do autor.

A questão das citações do cotidiano se materializa na obra dramatúrgica de Gógol, principalmente, no que se refere às peças metadramatúrgicas, onde o autor retratou a cena do público saindo do teatro após ver sua peça (no caso de $A$ saída do teatro depois da representação de uma nova comédia) e o caso dos atores dialogando após uma das apresentações da peça $O$ inspetor geral (em $O$ desenlace de $O$ inspetor geral). Percebe-se a necessidade que Gógol sentia de poder materializar seus pensamentos em sua escrita, não somente como um registro, mas que, através dela, pudesse estabelecer um diálogo com o leitor/espectador. A presentificação dessa verdade impressa na história criada por Gógol aproxima o leitor, através do emprego da metadramaturgia, dos aspectos que o autor quer destacar, do seu projeto existencial, e se dissolve na subjetividade da sua escrita.

Para usarmos um exemplo, entre tantos presentes na dramaturgia de Gógol, podemos dizer que, em sua obra, os aspectos teatralizantes (podemos citar, como exemplo, a cena final de $O$ inspetor geral, onde os personagens terminam a cena estáticos) da realidade russa, assim como a forma com que a sociedade é vista e o humor ácido imposto em suas obras, nada mais é do que a comprovação da inserção do autor dentro da obra e de sua preocupação com os contornos da escrita para além de si mesmo. O que está colocado na obra de Gógol não é apenas uma visão histórica da Rússia ou uma fábula criada pelo autor, essa seria uma visão reducionista de sua obra. O que o escritor russo coloca, na sua trilogia metadramatúrgica, por exemplo, é sim, sua obra enquanto portadora de seu próprio discurso, de uma presença, no sentido que a obra adquire diante do contexto em que está inserida e fora dele.

O trabalho de se pensar a literatura pela via da performance, na obra de Gógol, vem da necessidade e da sucessiva produtividade, principalmente tratando-se de uma postura metodológica, em uma área ainda incerta, muitas vezes contraditória e movediça, que é o estudo da escrita performática, visto ser uma escrita que se preocupa menos "[...] com a literalidade do texto e mais com o projeto de experimentação da escrita em jogo" (Beigui, 2011, p. 31). Essa experimentação pode ser apontada na trilogia metadramatúrgica gogoliana, levando em consideração que a primeira 
obra dessa trilogia, $O$ inspetor geral, faz parte de suas experimentações a caminho do realismo e, nas duas últimas peças da trilogia, percebe-se um explorar dos desdobramentos ocasionados pela repercussão da primeira. Assim, Gógol tende mais ao trabalho com o desconhecido, com o que é inclassificável, ou que foge de uma nomenclatura, indo no sentido inverso da objetividade que visa enquadrar e conceituar. Sobre o viés da experimentação, podemos usar a trilogia metadramatúrgica gogoliana como exemplo, uma vez que o dramaturgo foge dos padrões de escrita de sua época para criar um discurso entranhado e cheio de significados, onde a plateia se vê e percebe o próprio teatro como matéria de crítica e intervenção da obra.

Toda obra de arte, e aqui estamos nos referindo especificamente à literatura, ainda que não diretamente, passa pelo viés do entretenimento, apesar de muitas vezes esse não ser o objetivo-primeiro do autor. A formação e modificação de uma realidade está diretamente ligada a essa à construção da literatura enquanto forma de exposição, crítica e de debate social, cultural e político. A partir da interferência do artista, ou a partir de sua presença na obra, o contexto pode ser alterado de diversas formas e, assim, a partir dessas mudanças, pautar o entendimento de uma comunidade sobre determinado tema ou situação, ao provocar e em alguns casos educar, em um contexto específico. Muitas vezes, a questão da cura através da dor é despertada a partir da não aceitação do indivíduo de uma realidade ou contexto específico. Podemos dizer que o ensinar, persuadir e/ou convencer na escrita performática está diretamente ligado ao ato transgressor da escrita, a capacidade que o autor tem de envolver o seu leitor/espectador, de fazer com que ele visualize as imagens presentes na obra e delas se apodere, transformando-as.

Sobre a escrita de si, Foucault afirma ser importante analisar "[...] a relação do texto com o autor, a maneira como o texto aponta para essa figura que lhe é exterior e anterior, pelo menos em aparência" (Foucault, 1997, p. 34). O que o filosofo tenta é lançar o olhar para o autor, não só enquanto mero executante de uma obra, encoberto pelo que ela representa e esquecido na sombra do seu conteúdo, mas também destacá-lo enquanto agente. Para exemplificar como isso ocorre na trilogia metadramatúrgica de Gógol, podemos citar as constantes intervenções e explicações de "O Autor da Peça" em À saída do teatro depois da representação de uma nova comédia, onde o personagem/autor desabafa todas as suas angústias, incertezas e revoltas. O discurso do personagem é o discurso do dramaturgo, que quer ser ouvido e, para isso, usa a escrita.

Segundo Foucault (1997, p. 45):

O nome do autor serve para caracterizar um certo modo de ser do discurso: para um discurso, ter nome de autor, o facto [sic] de se poder dizer 'isto foi escrito por fulano' ou 'tal individuo é o autor' indica que esse discurso não é um discurso quotidiano, indiferente, um discurso flutuante e passageiro, imediatamente consumível, mas que se trata de um discurso que deve ser recebido de certa maneira e que deve, numa determinada cultura, receber um certo estatuto.

Nesse sentido, pode-se dizer que o discurso de Gógol foi recebido como um discurso político, onde o autor frisava a insatisfação com o governo e denunciava a corrupção que ocorria entre os diferentes níveis de poder. Porém, esse não era o 
objetivo central de Gógol, ir diretamente contra o governo, mas sim o de mostrar a corrupção existente entre aqueles que exerciam poder.

Assim, é importante enfatizar, os traços que o autor deixa em sua obra, ou seja, o que chamamos de "projeto existencial do autor", aquilo que marca o autor em sua obra. Longe de ser um discurso distanciado da realidade, daquele que o escreve, trata-se de um discurso que carrega as marcas do seu "eu escrevente", suas relações com a cultura, com a sociedade e com a política de um determinado período. A exploração desses elementos é o que faz o autor ser representante de um dado período, ser o olhar sob o qual uma determinada época se mostra. Não um olhar neutro, distanciado, mas um olhar crítico, um olhar atuante, questionador, um olhar performático sobre uma determinada cultura. Nesse sentido, apesar de Gógol representar um dado período ele transcende a ele, sendo completamente atual e tratando de temas atuais para a nossa realidade. Sua obra se torna atemporal por tratar de questões que transcendem a Rússia em que o autor viveu e que deu impulso a sua escrita.

Para Foucault (1997, p. 274), “[...] o nome do autor não está localizado no estado civil dos homens, não está localizado na ficção da obra, mas na ruptura que instaura um certo grupo de discursos e o seu modo singular de ser". A questão da ruptura é tratada enquanto aspecto de uma escrita em que o autor se coloca frente ao seu tempo, muito além de convenções sociais ou literárias, rompendo com padrões e criando uma obra que apresenta uma realidade ficcionalizada segundo a sua visão. $A$ partir dessa definição, pode-se dizer que Gógol provocou rupturas no que diz respeito à relação do teatro com a política, em sua época, uma vez que, diante de um regime czarista, o dramaturgo expõe, ao próprio olhar do governante maior do estado, as corrupções que envolvem o governo. Além disso, para abordar aspectos da universalidade da sua obra, podemos dizer que Gógol, ao criar e compor seus personagens corruptos, nos mostra o que há de corruptível em cada um de nós. Nesse sentido, a potência política é um dos aspectos do discurso gogoliano que merecem destaque, atualizando a obra do autor.

\section{Considerações finais}

Ao final dessa reflexão, podemos entender que a "escrita de si", assim como colocada por Foucault, é uma escrita em que o autor é presente (se presentifica), não somente no momento da escritura do texto, mas enquanto "eu escrevente", ou seja, agente ativo de uma realidade, que não se esconde através dos signos tão diversos da literatura, mas sim, um autor que se expõem e utiliza sua obra como instrumento para traduzir as suas pulsões, aquilo que o move. O conceito de "escrita de si" tem muitos pontos de interseção com a ideia de uma escrita performativa. Em ambos os casos, temos o "eu escrevente" e o "coescritor performático", como principais agentes propulsores de uma comunicação pautada em uma escrita viva e atuante. Esse "eu escrevente" é o que chamamos de "autor performer", um autor que vai além da simples narração de uma história ou de um fato, um autor que busca, em sua obra, mecanismos de mudança de realidade, de paradigmas, que não se prende ao que está estabelecido, que está em sintonia com seu tempo e, algumas vezes, à frente dele. $O$ "autor performer" não se diferencia do performer dos anos 60 , momento 
em que a performance enquanto linguagem ganhou força e, por isso, é considerado um autor, um "eu escrevente" que sabe da importância da sua obra, não só para o registro de sua época, mas para trabalhar com as pulsões, com as motivações, com aquilo que para si é indissociável de sua realidade física, moral e estética. Por se tratar de um conceito relativamente novo e ser, em sua constituição, um conceito vivo, em constante atualização, a escrita performática traz consigo uma gama de significados que não nos permite fechar uma definição. Por ora, podemos falar em princípios que permitem nortear uma possível forma metodológica de analisarmos obras literárias a partir desse viés.

Não se pode deixar de relacionar a escrita performativa com a metadramaturgia impressa nas obras do autor russo. Esses dois conceitos permitem afirmar a contemporaneidade da obra gogoliana, a potência política de suas peças que, principalmente no que se refere à trilogia metadramatúrgica, apontam para uma obra que está além do seu tempo e nos faz refletir sobre a importância de trazer esse autor para junto de nós. Nesse sentido, embora a produção de Gógol date do início do século XIX, pode-se afirmar, a partir da análise desenvolvida no decorrer deste estudo, que seus textos são percursores da performatividade da escrita.

\section{Referências}

BARTHES, Roland. O prazer do texto. Tradução J. Guinsburg. São Paulo: Editora Perspectiva, 2006.

BEIGUI, Alex. Guimarães Rosa ou o narrador como performer. In: Recorte - Revista Eletrônica, Vol. 10, Número 02, p. 01-13, julho/dezembro, 2013.

Performances da escrita. In: Revista Aletria, Vol. 21, Número 01, p. 27-36, janeiro/abril, 2011.

FOUCAULT, Michel. Linguagem e literatura. In: Foucault, a filosofia e a literatura. Rio de Janeiro: Jorge Zahar Editor, 2001.

UFMG, 2011.

. O que é um autor? Organização de Sônia Queiroz. Belo Horizonte: FALE/

GÓGOL, N. Nikolai Gógol: teatro completo. Organização, tradução, prefácio e notas de Arlete Cavaliere. São Paulo: Ed. 34, 2009.

KLINGER, Diana Irene. Escritas de si, escritas do outro: o retorno do autor e a virada etnográfica. Tese. Rio de Janeiro: UFEJ - Instituto de Letras, 2006.

LEAL, Juliana Helena Gomes. Escrita performática latino-americana contemporânea. In: XI Congresso da ABRALIC, São Paulo, 2008. 
NABOKOV, Vladimir. Lições de Literatura Russa. Tradução Jorio Dauster. São Paulo: Três Estrelas, 2014.

PAVIS, Patrice. A Encenação Contemporânea: origens, tendências, perspectivas. São Paulo: Perspectiva, 2010.

PEDRON, Denise. Um olhar sobre a performatividade na cultura contemporânea: a performance como conceito e a produção artística de Diamela Eltit. Tese (Doutorado). Minas Gerais: UFMG - Faculdade de Letras, 2006.

RAVETTI, Graciela. Ficción y performance en escritores lationoamericanos contemporáneos. In: Diálogos latinoamericanos 4. Aarhus: Centro de Estudios Latinoamericanos, 2001.

SEIXAS, Rebeka Caroça. Metadramaturgia e escrita performática na obra dramatúrgica. Tese (Doutorado). Rio Grande do Norte: UFRN - Centro de Ciências Humanas, 2016.

ZUMTHOR, Paul. La medida del mundo: representación del espacio en la Edad Media. Madrid: Ediciones Cátedra, 1994.

Performance, recepção, leitura. São Paulo: Educ, 2000.

Recebido em: 30/04/2017

Aprovado em: 23/08/2017 